\title{
АНТРОПОСОФСЬКИЙ ПІДХІД ДО НАВЧАННЯ ТА ВИХОВАННЯ ОСОБИСТОСТІ
}

\author{
В. І. Лозова \\ чл.-к. НАПУ України, почесний професор ХНПУ імені Г. С. Сковороди
}

О. М. Іонова

Сучасні тенденції суспільного розвитку зумовлюють зміни пріоритетів вітчизняної освіти: вищою цінністю стає особистість з її потребами в самоактуалізації, саморозвитку, реалізації творчого потенціалу, підвищується роль внутрішніх детермінант у забезпеченні особистісно-соціального зростання людини. Такі орієнтири освіти передбачають узгодження освітніх завдань із природним розвитком людини, наближення педагогічного процесу до максимально повного розкриття внутрішнього потенціалу особистості, а отже, вимагають людинознавчого обгрунтування та здійснення навчання й виховання зростаючого покоління.

Проблема антропологічної орієнтації педагогічного процесу не є новою ані для вітчизняної, ані для світової педагогіки. Антропологічними ідеями, розумінням суті освіти як процесу всебічного розвитку людини були пронизані погляди мислителів Античності, Середньовіччя, епохи Відродження. Подальший розвиток і збагачення антропологічна традиція отримала у працях і практичній діяльності видатних філософів, психологів, педагогів різних часів і народів (О. Больнов, Я. Коменський, Г. Ноль, Й. Песталоцці, М. Пирогов, Ж. Піаже, Й. Ріттер, Г. Сковорода, В. Сухомлинський, К. Ушинський, К. Ясперс).

Активно та плідно антропологічні ідеї розроблялися Рудольфом Штайнером - фундатором вальдорфської

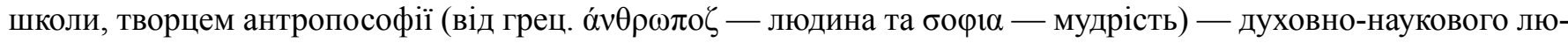
динознавства.

Пізнання природи дитини, за Р. Штайнером, є одночасно вихідним пунктом і смислом педагогічного процесу, основою виховання й викладання. Завдання антропології полягає у виявленні того особливого, що робить людину людиною, що відрізняє людське буття від буття інших істот.

У працях Р. Штайнера представлено фундаментальний виклад антропософського образу людини як частки й породження Всесвіту, розглянуто розумові, емоційні й вольові аспекти людської істоти в їх прояві на різних стадіях життя, а з огляду на це - обгрунтовано синтез підходів до викладання шкільних дисциплін. Нові педагогічні ідеї, нововведення, що були запропоновані Р. Штайнером у перший третині XX століття, i до сьогодні залишаються актуальними, сучасними й інноваційними.

Разом із тим у вітчизняній і світовій літературі відчувається явна нестача серйозних досліджень спадщини Р. Штайнера, який зумів привнести в життя багатьох людей і різні галузі культури імпульси пізнання й розвитку. Нерідко спостерігаються поверхові й необгрунтовані думки, некомпетентні спроби критики його дітища - антропософії.

Отже, метою дослідження $є$ висвітлення антропософських уявлень, які становлять осередок образу людини у Штайнер-педагогіці.

У ході наукового пошуку використано такі методи дослідження: теоретичні - системно-структурний, проблемно-цільовий, порівняльний методи, логічний аналіз, синтез для вивчення наукових джерел, систематизації й узагальнення антропософських ідей щодо образу людини; емпіричні - методи психолого-педагогічного спостереження, самоспостереження, самооцінки для підтвердження правомірності антропософських уявлень про суть людської істоти.

Проведений аналіз творчої спадщини Р. Штайнера дозволяє дійти висновку про те, що сформований ним образ людини базується на низці антропософськи зорієнтованих положень, основними з яких є такі: суть людини як тілесно-душевно-духовної істоти, співвідношення душевного життя особистості й їі тіла, з одного боку, та душі і духу, з іншого; уявлення про розвиток людини в ритмі семи років.

Зупинимося на цьому детальніше.

Р. Штайнер, як багато його попередників, уважав, що проблему розробки істинної психології особистості можливо вирішити лише в разі, якщо в основу розгляду людської суті буде покладене уявлення про людину як триєдність тіла, душі й духу. Те, що людська істота представляє собою як фізична істота, «кожною своєю частиною походить із духовно-душевного; отже, немає нічого фізичного, що не було б одкровенням духовнодушевного» $[7 ;$ с. 59$]$.

Формуючи образ людини як урегульовану взаємодію тілесних та душевно-духовних функцій і видів діяльності, у якій пріоритетну роль має найвищий принцип людини - iї духовні індивідуальні сили, Р. Штайнер наголошує на тому, що антропософія, як учення про духовно-наукову основу людини, ні в якому разі не зменшує значення життя фізичного тіла. Так, зокрема свою головну мету в галузі мистецтва виховання антропософія вбачає в тому, щоб зберегти здоровим фізичне тіло, «а це означає застосовувати такі духовні засоби засоби виховання й освіти, завдяки яким фізичний організм людини у зрілому віці буде найменшим чином 
здійснювати опір духовному боку життя. Висунувши перед педагогікою шкільного віку таку мету, ми зробимо все, що необхідно, щоб довірена нам людська істота виросла істотою вільною» [8; с. 54-55].

Іншими словами, головна мета процесів навчання й виховання полягає в забезпеченні здорового розвитку тілесно-фізичного як основи вільного вияву душевного-духовного дитини. І таким чином поняття «виховання до свободи» і «виховання до здоров’я», за Р. Штайнером, виступають як тотожні й синонімічні.

Важливе значення для забезпечення гармонійного розвитку людини є усвідомлення взаємовпливу ї̈ miлесного, душевного й духовного буття.

У триєдності тіла, душі та духу людська душа охоплює два полюси - сферу фізичного та сферу духовного. Із фізичного світу походять інстинкти й потяги. Тіло людини, підкоряючись певним законам, завжди розвивається до однієї, висунутої з самого початку, мети - до зрілого організму. У цьому процесі основну роль відіграють механізми створювання, рівновага й занепад. У духовній сфері людська душа знаходиться в реальному духовному світі, де власне «Я» людини перебуває як духовна істота, яка осягається душею в усвідомленні власного «Я» та його осмисленні. На відміну від тіла дух, який проникає у свідомість людського «Я», орієнтований на майбутнє і прагне до свободи. Людська душа, знаходячись між сферами духовного та фізичного, $є$ тією ареною, на якій зустрічаються обидві сили, й де людина повстає як істота «тут і зараз».

За Р. Штайнером, для того щоб зрозуміти співвідношення душевного життя людини й їі тіла, з одного боку, та душі й духу, з іншого, необхідно виходити з троїчності тіла, душі й духу. Тобто виділяти в людському організмі (тілі) нервово-почуттєву систему, ритмічну систему (систему органів дихання і кровообігу) та систему обміну речовин і органів руху; у душевному житті - уявлення (мислення), почуття й волю; духовному елементі - стани неспання, сновидіння і сну $[6,7,9]$.

Кореляція між душевними виявами й органічними процесами в людському організмі здійснюється таким чином: мислення (уявлення) спирається на нервово-почуттєву систему; відчуття й емоції - на ритмічну систему; воля — на процеси обміну речовин і органів руху.

Зазначимо, що зв'язок між світом уявлень і нервово-почуттєвою системою достатньо відомий і добре вивчений науковцями. Водночас кореляція емоційно-почуттєвої та вольової сфер із людським організмом мало дослідженні в науці, насамперед у психології. Це, за Р. Штайнером, веде до перебільшення ролі нервово-почуттєвої системи, що, у свою чергу, призводить до невизнання самостійного життя як емоцій і відчуттів людини, так і ії вольового елементу. Окрім цього, три основні складники психічного життя людини - ії мислення, відчуття і волю — пов'язують лише з нервово-почуттєвою системою. Разом із тим завдання цієї системи це тільки забезпечення розумової діяльності людини [7].

Так, нервово-почуттєва система через уявлення опосередковує життя волі й обміну речовин. Отже, нерви необхідно розглядати як носії сприйняття, а саме носії сприйняття самих рухів; носіями ж душевного вольового елементу в тілі людини є процеси обміну речовин, що пронизують людський організм аж до м'язової діяльності. Психологічно неважко віднайти душевний елемент, спостерігаючи за діяльністю обміну речовин у організмі. Якщо вольове життя людини в порядку, тобто вона бадьора, повна енергії, то людина переживає це як внутрішню силу, внутрішню активність, що живуть у неї аж до м'язів. У людини ж з порушеним вольовим життям, яка переживає кризовий стан, виникає відчуття внутрішньої слабкості, в'ялості, що поширюється аж до м'язової та мускульної систем.

Схожим чином необхідно розуміти тілесну основу почуттів. Будь-яка емоція супроводжується певним процесом ритмічного функціонування циркулярної системи, тобто внутрішнє життя відчуттів супроводжує те, що відбувається у крові, утворенні лімфи, кисневому обміні. Нерви ж лише сприймають те, що відбувається безпосередньо між душевними відчуттями та ритмічними процесами в організмі. Наприклад, музичне переживання є врівноваженням слухового сприйняття і ритмічного процесу (дихання, кровообігу). Тобто вплив музики на людину безпосередньо переживається ритмічною системою, а те, що пережито в ритмічній системі, потім людина опосередковує через нерви і таким чином почуте народжується в нервово-почуттєвій системі як уявлення.

Ілюстрацією поглядів Р. Штайнера на взаємозв'язок душевного життя людини з усією тілесною організацією може слугувати життєвий досвід будь-якої людини: кожному відомо, як сильні переживання впливають на процеси дихання й кровообігу, порушують сон тощо. Так, у тяжкому душевному стані в людини виникає відчуття, ніби у грудях все стикається, вона може вдихнути, але не може видихнути, у неї холодіють руки, сповільнюється пульс. Злякана людина блідніє, пульс стає частішим, а серце готове «вистрибнути» 3 грудей. I сміх, і плач, і сором тощо - усе це відбивається як на диханні, так і на кровообігу.

Про взаємозв'язок душевного й фізичного свідчать і численні вислови, пов' язані з людськими органами. Наприклад, якщо людина приголомшена якою-небудь подію, вона може сказати, що «в мене перехопило дихання». Існує висловів досить багато, що стосуються серця людини. Так, у неординарних випадках людина може сказати, 
що їі «серце у п’ятки сховалося» або «серце обливається кров’ю» аж до того, що «серце розірветься». Ми часто передаємо «сердечний привіт», говоримо про «сердечне рукостискання», «золоте серце» (добру людину) тощо.

Твердження Р. Штайнера про те, що вся тілесність як ціле, а не тільки нервово-почуттєва система, утворює фізіологічну основу душевного життя людини, протягом ХХ століття отримало підтвердження в традиційній науці, насамперед завдяки досвіду психосоматичної медицини. Яскравим і переконливим підтвердженням результатів, отриманих Р. Штайнером, є також практичний досвід, досягнення в різних галузях антропософськи орієнтованої діяльності (вальдорфська школа, лікувальна педагогіка, медицина, фармацевтика тощо) [1, 2].

Як продовження й конкретизація досліджень суті людини Р. Штайнер розкриває людський образ, який випливає $з$ вище розглянутої тілесно-душевно-духовної людської побудови. Він розвиває уявлення про чотирьохелементну структуру людини, яка була відома ще за часів Аристотеля. Згідно з ученням Аристотеля людина є системою, яка складається з чотирьох основних складників: мінерально-фізичного; вегетативного (спорідненого рослинному світу); інстинктивного (спорідненого тваринному світу) та власне людського.

Аналогічним чином Р. Штайнер розглядає людину як єдність і взаємодію чотирьох організацій (сутнісних складників), кожна з яких має свій принцип дії, а саме [5, 6]: а) фізична (тілесний організм), що дає форму й образ людини у просторі; б) життєва, яка розгортається в часі, в узгодженості й взаємодії численних ритмів людського організму, кожний з яких спричиняє певний процес, а в сукупності ці ритми підтримують організм як ціле. Ця організація забезпечує життєві функції людини, іiі зростання, розвиток, біографію. Вона є основою найважливіших процесів у людині, які забезпечують їі мислення, здатність до запам'ятовування й забування (пам'ять), розгортання темпераменту, формування звичок тощо; в) душевна, що є носієм свідомості, прагнень, емоцій, бажань, радощів, пристрастей, інстинктів тощо. Ця організація як закономірно працююча система знаходиться поза простором і часом, але впливає на ритмічну організацію життєвої організації (кожна емоція, кожне уявлення або устремління прискорює або уповільнює певні ритми), а через неї - на фізичне тіло; г) «Я»- свідомість - найвищий принцип людини, іiі духовне сутнісне ядро, сумління, завдяки чому людина $\epsilon$ індивідуальною істотою, що відрізняє й піднімає ії над рослинним і тваринним світами. Саме людське «Я» відповідає за те, щоб життя й доля людини набули сенсу.

Важливим у концепції Р. Штайнера є уявлення про людський розвиток у ритмі семи років. Це пов'язано 3 тим, що людина «вписана» у Всесвіт і підпорядковується космічним закономірностям: життя людини, як і життя народу не є хаотичним потоком подій; циклічні закономірності небесних явищ виявляються в житті людини та в усіх земних відношеннях і стосунках.

Р. Штайнер наголошує на тому, що при народженні людини складники іiі єства — фізична, життєва, душевна організації та «Я»- свідомість - по-різному виявляються на фізичному плані й знаходяться на різних ступенях становлення. Розвиток людини є нічим іншим, як поетапним формуванням цих складників людської особистості в результаті послідовного «народження» фізичної, життєвої, душевної та «Я» організацій у моменти фізичного народження і у віці приблизно 7, 14 і 21 років відповідно [4].

Ця теза є базою вікової періодизації у Штайнер-педагогіці, яка виділяє такі три основні періоди становлення особистості до віку ранньої дорослості $[4,6,8]$ : період від народження до зміни зубів (до 7 років) період фізичної зрілості, переважного виховання тіла дитини; період від зміни зубів до статевої зрілості (7-14 років) - період психічної зрілості, коли акцент має робитися на вихованні душі; період від пубертату до ранньої дорослості (14-21 рік) — період соціальної зрілості, переважного виховання духу.

Зупинімося детальніше на трьох вище зазначених взаємопов'язаних напрямах виховання й розвитку людини — тілесному, душевному й духовному.

Так, фізичний розвиток дітей йде від «голови» через «груди» до «кінцівок», тобто «дитина виростає 3 голови». Дійсно, якщо подивитися на немовля, то перш за все кидається у вічі досить велика - порівняно з іншими частинами тіла — голова дитини. У процесі подальшого росту співвідношення розмірів голови та інших частин тіла стає гармонійним - як у дорослої людини. Окрім цього, саме в голові людини сконцентровані органи відчуттів, які відіграють головну роль у житті немовляти. У другому семиріччі акцент переноситься на розвиток грудної організації: якщо в новонародженої дитини дихання, пульс ще нерегулярні, нерівні, то після семи років вони стають ритмічними. У період статевого дозрівання в підлітках особливо інтенсивно ростуть руки і ноги, а голова майже не змінюється за розміром.

Душевна складова людини розвивається переважно від волі, яка закладається в першому семиріччі, через відчування до мислення. Розвиток вольової сфери дитини відбувається паралельно з формуванням фізичних органів, усієї тілесності. Яскравою ілюстрацією цього положення слугує поведінка дитини у віці до зміни зубів: вона постійно в русі, їі ручки і ніжки не знають покою.

Для розуміння, чому саме у віці з 7 до 14 років головним чином розвивається відчування людини, можна порівняти життя дитини-дошкільника і підлітка. У дошкільника життя почуттів спрямоване назовні: будь-які зміни в навколишньому одразу ж відбиваються на емоціях дитини. Життя почуттів підлітка на межі статевого 
дозрівання є замкнутим простором. Це пов'язане з народженням самостійної життєвої організації і тим самим 3 початком формування внутрішнього життя почуттів, яке аж до статевого дозрівання, у свою чергу, тісно пов’язане з діяльністю фізичного організму, що викликає замкнутість дитини від усього світу. Емансипація відчування в період пубертату дозволяє підліткові знову відкритися навколишньому світу та доторкнутися до нього власними душевними силами.

У період статевого дозрівання в людини відбувається народження самостійної душевної організації, яка є основою самостійного мислення, а отже, людина «отримує можливість розвивати об'єктивне пізнання природи і свою моральну свободу» [3; с. 39].

Духовний розвиток у віці від народження до ранньої дорослості має три основні ступені: усвідомлення «Я», що виникає на третьому році життя; переживання «Я», яке починається в 9-10 років і повністю розвивається у віці, що передує статевому дозріванню; прагнення до реалізації «Я» в юності. При цьому 3 кожним кроком духовного розвитку його попередні форми набувають нового змісту [2].

Духовний розвиток впливає на розвиток свідомості людини. Немовля ще не має усвідомленого душевного життя. Перші уявлення в дитини починають формуватися свідомо лише з появою постійних зубів. Стан свідомості дитини до семи років, яка переважно все робить неусвідомлено, Р. Штайнер порівнює зі «станом сну». Зі зміною зубів свідомість людини стає образною, наповненою фантазією, тому вона схожа 3 «мріями наяву або сном зі сновидінням». Із пубертатом людина може осягнути ясну, абстрактну думку і знає, як вона виникла, може пояснити складники логічної послідовності як для себе, так і для інших. І цю ступінь свідомості Р. Штайнер характеризує як «свідомість, що не спить» [6].

Розвиток людини протягом семирічного циклу йде не плавно, а має певні «критичні точки», у яких душевний світ дитини зазнає значних змін. Зокрема, період від зміни зубів до статевого дозрівання має три стадії, що пов'язано з тим, що в житті дитини чітко виділяються два основних моменти - приблизно в 9 (10) і 11 (12) років.

Р. Штайнер особливий акцент робить на тому, що хоча переміни в дитині тісно пов’язані з їі віком, проте на кожному віковому ступені необхідно стимулювати та спрямовувати процеси розвитку через виховання й навчання. Це створюють базу для розвитку духовної незалежності людини, формування почуття впевненості в житті, соціальної активності, глибокого інтересу до навколишнього життя.

Основні підходи до дитини з урахуванням специфіки ії віку полягають у тому, щоб у перші сім років вихованням прищепити дітям уявлення про те, що «світ добрий, моральний»; у другому семиріччі розвитку дитина має прийти до переконання, що світ повний радості й краси, що «світ прекрасний»; у третє семиріччя в людині необхідно пробудити прагнення до пошуку істини, вона має усвідомити, що «світ істинний» [6].

Так, завданням виховання інтелектуала необов'язково постійно й безпосередньо розвивати розумові здібності дитини. На ранніх етапах (дошкільний вік) діти продуктивніше вчаться через дії й рухи, пізніше - через розвиток фантазії й життя почуттів, яке поступово формується. Здатність же до власного абстрактного мислення, що з'являється зі статевим дозріванням, часто плутається з розумовим осягненням уже обдуманого кимось. По-справжньому творче мислення, яке може зробити людину незалежною від будь-яких нав'язаних ззовні уявлень, виявляється у підлітка лише в разі, якщо в нього вже наявні сформовані душевні сили відчування й волі.

Отже, перші вісім років у школі охоплюють період формування внутрішнього життя й виховання почуттів; у старших класах (9-12 класи) основою розвитку є вироблення здатності до самостійного мислення. Час і тривалість даних стадій розвитку незначним чином варіюються в різних учнів - на відміну від розвитку розумових та інших спеціальних здібностей. Проте перехід від однієї стадії до іншої не відбувається стрибкоподібно. Так, протягом перших трьох навчальних років відбувається ще значний розвиток волі, й у дітей виявляються особливості, характерні для віку наслідування. Дитяча всебічна схильність до наслідування на початку шкільних років має активно використовуватися через залучення в навчальний процес саме вольової сфери дитини. Водночас вольовий аспект учня через художнє викладання формує емоційне життя, яке починає досягати самостійності. Відповідно в навчанні й вихованні треба брати до уваги той факт, що під час перших навчальних років самостійне емоційне життя (або на початку старших класів самостійне мислення) ще не повною мірою розвинене: воно весь час знаходиться у процесі розвитку.

Отже, антропософська концепція розвитку людини базується на таких основних положеннях: єдність тілеснодушевно-духовного буття; зв'язок складників психіки з фізіологічною організацією людини (мислення - 3 нервово-почуттєвою системою, емоцій і почуттів - зі системою органів дихання та кровообігу, волі зі системою обміну речовин і органів руху); взаємозумовленість фізіологічного, душевного і духовного розвитку в ритмі семи років. Перспективним для подальших досліджень уважаємо проведення порівняльного аналізу антропософського підходу до людини з існуючими сучасними психолого-педагогічними концепціями особистості. 


\section{Література}

1. Ионова Е. Н. Вальдорфская педагогика: теоретико-методологические аспекты: монография. Харьков : БизнесИнформ, 1997. 300 с.

2. Ливехуд Б. Кризисы жизни - шансы жизни / пер. с нем. Н. П. Банзелюка. Калуга : Духовное познание, 1994.224 с.

3. Штайнер Р. Космология, религия и философия / пер. с нем. под ред. Н. П. Банзелюка. Калуга : Духовное познание, 1996. 176 c.

4. Штайнер Р. Воспитание ребенка с точки зрения духовной науки / пер. с нем. Д. Виноградова. М. : Парсифаль, 1993. 40 с.

5. Штайнер Р. Духовное водительство человека и человечества / пер. с нем. Н. П. Банзелюка. Калуга : Духовное познание, 1992. 40 с.

6. Штайнер Р. Общее учение о человеке как основа педагогики / пер. с нем. Д. Виноградова. М. : Парсифаль, 1996.176 с.

7. Штайнер Р. Духовное обновление педагогики /пер. с нем. Д. Виноградова. М. : Парсифаль, 1995. 256 с.

8. Штайнер Р. Духовно-душевные основы педагогики / пер. с нем. изд-ва «Парсифаль». М. : Парсифаль, 1997.144 с.

9. Штайнер Р. Современная духовная жизнь и воспитание / пер. с нем. Д. Виноградова. М. : Парсифаль, 1996. 208 с. 